\title{
Homoseksualiteit: Die kerk, die tradisie en die Bybel - homofobie en sarkofobie en die evangelie ${ }^{1}$
}

\author{
Yolanda Dreyer \\ Departement Praktiese Teologie \\ Universiteit van Pretoria
}

\begin{abstract}
Homosexuality: Church, tradition, and the Bible homophobia, sarcophobia, and the gospel

The article demonstrates a trend in the current debate on the church's attitude towards homosexuality, namely that exegetical results supersede authentic faith experiences of gays. It shows that this trend causes an untenable tension between the dialectical notions sola fidei and sola Scriptura. Such an unacceptable tension contributes to the social psychological phenomena of homophobia and sarcophobia. The article investigates this empirical approach (theoretical reason) to homo-sexuality from the dialectical perspective of a theological approach (practical reason). The latter includes an investigation of the epistemological processes behind exegetes' diverse use of Scripture. The article aims to show that homophobia in society and church, and the sarcophobia of homosexuals can be challenged and healed if the church holds on to the dialectic between sola fidei and sola Scriptura and the dialectic between pastoral concerns and the engagement with the gospel of Jesus Christ.
\end{abstract}

\section{DIE PROBLEEM}

Die uitgangspunt van hierdie artikel is dat die Skrif die riglyn is vir gelowige mense se gedrag. Gedrag het te doen met verhoudings en interaksie tussen mense. Die probleem ten opsigte van homoseksuele gedrag het twee kante. Enersyds is dit 'n verskynsel dat sommige mense homoseksueel is en dit beoefen. Andersyds is sekere persone homofobies. Dit is ' $n$ irrasionele vrees vir en weersin in homoseksualiteit. Homofobie lei tot sarkofobie, 'n irrasionele

\footnotetext{
${ }^{1}$ Hierdie artikel word opgedra aan Piet Geyser met dank vir ' $n$ kosbare vriendskap van byna 20 jaar, by geleentheid van sy aanvaarding van emeritaat as professor aan die Fakulteit Teologie, Universiteit van Pretoria. Ek betuig ook my dank vir die bydrae van die nagraadse student, Fanie Beukes, tot sekere aspekte van hierdie navorsing.
} 
vrees en haat vir die eie of ander se mens-wees en liggaam. Wanneer homoseksuele mense homofobie van medegelowiges en kerklidmate ervaar, beleef hulle innerlike konflik tussen die self en die kerk se geïnstitusionaliseerde norme, veral dié wat op die Bybel gebaseer is. In The Encyclopedia of Homosexuality (Johansson 1990:648-649; vgl Ellison 1993:149) staan die volgende: "For homosexuals the Judeo-Christian tradition has meant nothing but ostracism and punishment, exile and death ..."

In die kerk is daar twee direk teenoorstaande standpunte wat albei ' $n$ beroep doen op die Skrif. Beide kante probeer weergee wat die tekste "werklik beteken" binne hulle kulturele konteks. Die argumente van albei kante is in 'n sin "biblisisties" (kyk Seitz 2000:177). Die debat oor homoseksualiteit het die kerk en akademie voor 'n krisis te staan gebring. Daar is wyd uiteenlopende menings oor homoseksuele gedrag. Eweneens is daar uiteenlopende sienings oor hoe die Skrif normatief behoort te funksioneer. In die Ou Testament word geslagtelike verskeidenheid Goddelik gelegitimeer en "homoseksuele" gedrag uitdruklik veroordeel. Van die Ou na die Nuwe Testament het godsdienstige sienings egter onwikkel. Wat vroeër uitdruklik veroordeel is, word later versag. Die teensprake en konflik in die kerk dra by tot die marginalisering van homoseksuele persone. Hulle beleef dat die kerk dubbel praat en intussen vind hulle nie 'n tuiste in die kerk nie.

Die term "homoseksualiteit" is vreemd aan die Bybel se taalgebruik. Dit kom nêrens in die Bybel of wêreld van die Bybel voor in nie. Die term "homoseksueel" is uit die Duits in Engels oorgeneem in 1892. Dit kom nie van die Latyn homo (mens) nie, maar van die Grieks homoios ("soos" of "dieselfde"). Dit het te doen met seksuele oriëntasie op dieselfde geslag (Edwards 1984:14; vgl Bellis \& Ogden 2002:17; Via 2003:1;). Die verskynsel homoseksualiteit kan dus nie direk vanuit die Bybel verstaan word nie. Dit sou ondersoek moet word in die verlengstuk van die ontwikkeling van die Ou Testament, na die Nuwe Testament en verder (kyk o a Brooten 1996).

Aanvanklik het die kerk gemeen dat die Ou en Nuwe Testament "homoseksualiteit" uit een mond veroordeel. As gevolg van insig in die ontwikkeling van die begrip "homoseksualiteit" het ' $n$ histories-kritiese analise van die tekste 'n meer komplekse prentjie begin uitwys en "the older concensus about the plain sense of Scripture on this issue began to collapse" (Seitz 2000:178).

Indien aangetoon kon word dat die Bybel homoseksuele dade verbied as onaanvaarbaar vir God in Christus, is die vraag of dit genoeg rede vir die kerk sou kon wees om homoseksuele gedrag vandag af te wys. Die konsekwensies hiervan word deur Seitz (2000:181) uitgespel: "That this immediately raises the question of appropriate pastoral care is obvious and 
reminds one how allergic the church has become to dealing with matters of the flesh in general, as central to the disciplined Christian life." Indien daar "ja" geantwoord word op die vraag, sal die kerk baie ernstig moet nadink oor die verantwoordelikheid ten opsigte van die pastorale versorging van mense. Die uitdaging aan die kerk om hierdie moeilike pastorale dimensie van gepaste seksuele gedrag effektief te verdiskonteer, wys dadelik uit dat die antwoord op bogenoemde vraag nie eenvoudig of vanselfsprekend is nie.

Twee standpunte ten opsigte van die gesag van die Bybel is van belang. Die eerste is dat die Bybel 'n enkelvoudige boodskap (plain sense) oor homoseksualiteit het, maar dat die gesag daarvan nie aanvaar word nie. Daarteenoor is die tweede standpunt dat die Bybel glad nie so 'n enkelvoudig boodskap oor die saak het nie. Verder is daar homoseksuele persone wat hulle seksualiteit beskou as "teen die Bybel", maar oordeel dat dit nie verkeerd kan wees as dit binne 'n liefdevolle, "committed" verhouding uitgeleef word nie.

Diverse uitsprake oor "homoseksualiteit" in die Bybel skep die moontlikheid om te verskil oor watter tekste, kontekste en perspektiewe die bepalende is in die lig waarvan ander tekste geïnterpreteer behoort te word. Die Lutherse hervorming (wat in sekere opsigte berus op standpunte van Augustinus) sien op punte wet en evangelie as in opposisie tot mekaar en onderskei tussen "Paulus" (evangelie) en "Moses" (wet). Die wet van God het nie verval of ongeldig geword nie, maar word in Christus, of deur Christus vervul. In Christus vind die gees van die wet vervulling: die letter van die wet word nie in eie krag gehoorsaam nie, maar in Christus word dit op grond van genade moontlik om die wil van God te doen. Die verhouding met Christus gaan nie om die nakoming van die wet op 'n legalistiese wyse nie, maar om nuwe moontlikhede van verhouding met God waarin die mens vry van sonde en dood kan lewe. Dit beteken 'n lewe nie volgens die menslike natuur (sarks) nie, maar volgens die Gees van God (pneuma). Die sistematiese teoloog, Eberhard Jüngel (1962:266) beskou die Pauliniese uitspraak dat outentieke lewe op geloof alléén (sola fidel) berus, as 'n kompakte verklaring van die boodskap, lewe en dade van die historiese Jesus (vgl Van Aarde 2000:549571; 2002:516-532).

Jesus praat nie oor homoseksualiteit nie. Die afleiding word egter gemaak dat, omdat homoseksuele gedrag en egbreuk in dieselfde asem genoem word in die riglyne vir seksuele gedrag in Levitikus 20:13, Jesus dieselfde op albei sou reageer. Dit beteken dat Jesus nie sou toelaat dat die sondaar veroordeel word nie, maar hom of haar sou wegstuur met die opdrag: "Gaan, en moenie meer sonde doen nie." 
Die Bybel sê ook nie veel oor homoseksuele gedrag nie. Dit kan wees omdat dit nie algemeen voorgekom het in Israel nie. Waar daar wel oor homoseksuele gedrag gepraat word, word dit uitgesonder as 'n sonde op dieselfde vlak as egbreuk, bloedskande en bestialiteit en in Levitikus 20:10-16 en aangedui as 'n sonde wat die doodstraf verdien. Omdat die Ou Testament sterk klem lê op hierdie sondes, meen sommige teoloë dat hulle nie maar net verbygegaan kan word nie. In die Nuwe Testament word homoseksualiteit op een lyn geplaas met woede en gierigheid. Dieselfde argument geld. Dit word beskou as "sondes" waarvoor net die liefde van God in Christus genoegsaam reddende krag het om mense daarvan te bevry. Om liefde in dieselfde asem te noem met homoseksuele gedrag, sou dus wees soos om positief te praat oor gierigheid of dronkenskap (vgl Seitz 2000:189-190). Die soort gedrag kan geen seën wegdra nie.

Die probleem met so 'n redenasie is dat daar in die hermeneutieseksegetiese proses spanning gekom het tussen sola fidei en sola Scriptura. Eksegetiese "skrifgeleerdheid" neem voorrang bo die mens se geloofsverhouding met God. Die teologiese probleem hiermee is dat die gawe van geloof van "skrifgeleerdheid" (die eksegese van [geïsoleerde] Bybeltekste) afhanklik gemaak word. Eksegese skep egter nie geloof nie. Dat die kerk paradoksaal volhou om aan die een kant homoseksualiteit op grond van die Skrif as sonde te veroordeel en aan die ander kant gelowige homoseksuele persone met pastorale warmte te wil benader, is 'n gevolg van hierdie spanning. Teologies-hermeneuties gesproke kan hierdie dubbelpraat net geregverdig word as kernaspekte van die dialektiese teologie geïgnoreer word. Sonder 'n dialektiese uitgangspunt word dit moeilik om die bekende indikatief-imperatief, "word wat jy in die geloof reeds is", te handhaaf. Dan word mens-wees op sigself as sondigheid getipeer. Volgens Paulus is sonde die futiele strewe om die heil te wil bou op verganklike mens-wees. Om mens (sarks) te wees, is net so min sonde as om 'n bepaalde kleur oë of 'n liggaamlike gebrek te hê - ongeag of iemand daarmee gebore is of so geword het. Ook die betekenis van Jesus se kruisdood en opstanding, naamlik dat God se krag (genade) in swakheid (verganklike mensheid) realiseer, kan moeilik sonder dialektiese denke begryp word. Om genade te vind buite die werke van die verganklike mens, beteken nie om te kom tot selfhaat ("sarkofobie") nie. Dit lei eerder daartoe dat God se teenwoordigheid in en deur die Gees van God te midde van en ten spyte van mens-wees met vreugde ervaar kan word.

Die doel van hierdie artikel is om te wys op die spanning tussen sola fidei en sola Scriptura in die kerk se refleksie op homoseksualiteit. Hierdie spanning dra by tot die anomalie in die institusionele kerk dat 
homoseksualiteit as sonde veroordeel word, terwyl daar tegelykertyd gepleit word vir die deernisvolle pastorale versorging van homoseksuele persone. In 'n onbeholpe poging om die anomalie te ontkom, onderskei die kerk tussen die mens as sondaar en die sondige dade van die mens - asof daad en mens werklik geskei kan word. So 'n standpunt dra by tot die selfhaat van gelowige homoseksuele persone. Dit word 'n etiese probleem wanneer die kerk wat hiertoe bydra, in dieselfde asem 'n pastorale antwoord tot heelwording van die persoon wil bied. Die kerk dra by tot die skep van spanning by veral gelowige homoseksuele persone. Die oorsprong van hierdie konflikervaring is verwante verskynsels wat bekendstaan as "homofobie" en "sarkofobie".

Daar word dikwels aanvaar dat Paulus sarks in 'n negatiewe lig sien. Wanneer sarks met seksualiteit verbind word, word geoordeel dat die Nuwe Testament as sodanig negatief is ten opsigte van seksualiteit. Ander meen weer dat Paulus hoegenaamd nie negatief is in sy siening oor sarks nie. Elizabeth Edwards (1996:70-71; vgl Bultmann 1951:235-236) beredeneer dat Paulus wel by geleentheid negatief was oor sarks omdat hy dit gesien het as die oorsaak dat mense uit swakheid sonde doen. Ander kere gebruik hy die begrip neutraal in die sin van iets natuurliks, iets wat te doen het met verganklike mens-wees en dinge. Verder gebruik hy dit in die sin van 'n bedeling of tydperk van bestaan. Edwards (1996:70-71) onderskei ses kategorieë van Paulus se gebruik van sarks. Kortliks kan die kategorieë saamgevat word as: alles wat verwys na menslikheid en wat met die mens te doen het; fisiese verhoudings; simbolies van wat teenoor God is; simbool vir uitgelewer wees aan, beheer word deur die sarks maar ook as gevolg van die sarks. Dit gaan dus om alles wat te doen het met mens-wees-in-die-wêreld en om wat die mens kan wegkeer van God af of teenoor God te staan bring.

Wanneer Paulus praat oor soma (liggaam), is hy baie meer positief as oor sarks. Die mens wat lewe volgens die Gees van God (pneuma) oorstyg die sarkikos-bestaan sonder om op te hou om sarks te wees. Vir so 'n bestaan gebruik Paulus die term soma. Wanneer hy die kerk soma van Christus noem, bedoel hy die ruimte waar pneumatiese mense lewe - in God se teenwoordigheid te midde van en ten spyte van hulle sarkikos-bestaan. Volgens Paulus in I Korintiërs 15:44 word die "natuurlike liggaam" (sarkikosbestaan) op grond van die dood en opstanding van Jesus Christus pneumaties getransendeer in 'n "geestelike liggaam ('n psuchikos, ofte wel 'n somatiese bestaan). Dit is 'n eskatologiese gebeure wat reeds in hierdie lewe plaasvind. Volgens 1 Korintiërs 12:12-31 is die kerk die ruimte waarin die "geestelike liggaam" eksisteer. Hierdie "liggaam" bestaan uit baie lede en elke lid het 'n eie sarkikos-bestaan. Die "baie" vorm 'n eenheid want almal het op grond van die dood en opstanding van Jesus deel aan God. So vorm die 
"baie" die "één liggaam van Christus". In die kerk word sarks nie opgehef nie, maar diensbaar gestel aan God.

Julle moet geen deel van julle liggame in diens van die sonde stel as 'n werktuig om goddeloosheid te bedrywe nie. Nee, stel julle in diens van God as mense wat dood was maar lewend gemaak is, en stel elke deel van julle liggame in diens van God om te doen wat God wil. Die sonde moet nie meer baas wees oor julle nie, want julle staan nie onder die wet van Moses nie, maar onder die genade.

(Rom 6:13-14)

Daarom gaan die argument van Edwards (1996:74) en ander nie op dat Paulus se gebruik van sarks nie die Christelike siening van seksualiteit as 'n positiewe, noodsaaklike deel van mens-wees en as 'n gawe van God dien nie.

Hierdie artikel wil aantoon dat homofobie en sarkofobie nie geregverdig kan word op grond van die evangelie nie. Paulus se onderskeid tussen pneuma (die Gees van God) en sarks (verganklike/feilbare mens-wees) beteken dat 'n gelowige net outentiek kan lewe in 'n pneumatiese bestaan en nie op grond van 'n sarkikos-bestaan nie. 'n Lewe volgens sarks is dat 'n sinvolle bestaan gesoek word in die krag van mens-wees en feilbare dinge. So 'n soeke lewer niks op nie. Net God se genade en die gawes van God se Gees (charismata) kan sinvolle en outentieke lewe vir mense moontlik maak. Dié evangeliese boodskap beteken egter nie dat die pneumatiese mens ophou om as eindige wese (sarks) te bestaan nie. Ook het 'n sarkikosbestaan steeds wel waarde vir die alledaagse lewe van 'n gelowige wat in 'n sinvolle relasie met God lewe. Die vraag is of homoseksualiteit so 'n waardevolle aspek van 'n mens se sarkikos-bestaan is, en of dit onversoenbaar is met 'n outentieke bestaan voor God. Indien dit nie versoen kan word met 'n pneumatiese bestaan nie, kan 'n homoseksuele mens nie as 'n gelowige beskou word nie. Sarkofobie sal die gevolg wees. Die resultate van studies oor homoseksualiteit op die gebied van die sosiale en menswetenskappe bevestig dat homoseksualiteit per se nie skadelik is nie, maar wel homofobie en sarkofobie. 'n Teologie wat die dialektiek tussen 'n (teologiese) simboliese wêreld en 'n sosiale wêreld (kyk Berger 1969, 1973, 1992) in ag neem, kan die resultate van hierdie sosio-psigologiese navorsing nie ignoreer nie, veral as dit die outentieke spiritualiteit van Christene in die gedrang sal bring.

Die plan van die artikel volg die dialektiese (Kantiaanse) patroon van eers hoor wat die wetenskap empiries te sê het oor die mens-wees van homoseksuele persone en dan kyk hoe hulle mens-wees hulle ervaring 
beïnvloed. Dit sluit hulle geloof in God en hulle ervaring van sowel die institusionele kerk as van medegelowiges in. (Jones \& Yarhouse 2000a se werk neig om wetenskap en teologie in konflik met mekaar te hanteer: óf die wetenskap is reg en die Bybel verkeerd, óf andersom.) Die artikel sal aantoon hoe die kerk se Bybelgebruik en handhawing van tradisionele kultuurkonvensies (bv ten opsigte van die huwelik) ' $n$ invloed gehad het op die samelewing se siening. Dit wil ook aandui wat die bydrae is wat die sosiaalwetenskaplike studies (psigologies en sosiologies) maak om die verskynsel homoseksualiteit en die mens-wees van gays beter te verstaan.

Navorsingsresultate toon aan dat, hoewel die regstelsel homofobie onaanvaarbaar vind, speel die kerk 'n rol daarin dat Christelike verdraagsaamheid nie deur baie kerkmense uitgeleef word nie. Die uitdaging vir die kerk is om sarkofobie in die lewens van gays wortel en tak uit te roei en nie langer daartoe by te dra nie. Om ruimte te bied vir die geloof van gays (sola fidei) beteken nie om die Bybel (sola Scriptura) te negeer nie.

In hierdie artikel word nie eksegese gedoen van die gedeeltes wat tradisioneel met homoseksualiteit in verband gebring word nie. Heelwat publikasies het reeds die ekegetiese navorsingsresulate verwoord (kyk o a Seow 1996:17-34; Germond 1997:211-232: Bellis \& Hufford 2002:93-122; Geyser 2002:1655-1677). Hier word eerder aandag gegee aan die dinkprosesse (epistemologieë) ten grondslag van die konflikterende eksegetiese resulate wat voortvloei uit 'n verskil in Skrifverstaan.

\section{SOLA SCRIPTURA - DRIE PERSPEKTIEWE}

\section{1 'n Objektiewe Skrifverstaan}

Die algemeen aanvaarde standpunt van die kerk is dat die geopenbaarde wil van God twee seksuele moontlikhede toelaat: die heteroseksuele huwelik of selibaat buite die huwelik. Homoseksuele praktyke word derhalwe as inherent immoreel gesien (Jones \& Yarhouse 2000b:73-74, 118-119; vgl Via 2003:18) en daarom verbode. Dit maak dan nie saak of dit 'n relasie van liefde is wat nie promisku is of waar die een die ander uitbuit nie. Die heelheid van die betrokke mense, hulle intensies of die gevolge wat hierdie standpunt inhou, word nie verdiskonteer nie (kyk Jones \& Yarhouse 2000b:73, 82).

Jones \& Yarhouse (2000b:112-114) aanvaar nie die bestaan van soiets soos "seksuele oriëntasie" nie. Hulle gee toe dat genetiese faktore, breinstrukture en die hormone van die ouer 'n "neiging" tot homoseksualiteit kan veroorsaak in 'n sekere groep van die bevolking. Daarmee saam aanvaar hulle dat sosiale en psigiese faktore ook 'n rol kan speel. Dit sluit egter nie menslike keuse uit nie. Vir hulle is wetenskaplik-empiriese gegewens van minder belang in die Christelike etiese nadenke. Selfs as wetenskaplike 
gegewens dus sou aantoon dat homoseksualiteit algemeen is, nie verband hou met psigiese probleme nie, geneties veroorsaak is en onomkeerbaar is, sou die tradisionele standpunt op 'n nie-dialektiese wyse net op etiese en teologiese argumente gegrond word en nie ook op sosiaal-wetenskaplike gegewens nie (Jones \& Yarhouse 2000b:118-120).

Volgens hierdie standpunt speel die sosio-kulturele konteks nie so 'n belangrike rol wanneer oor etiese kwessies besluit word nie. Dit het hermeneutiese konsekwensies. Die fokus op dade haal die mens as geheel met sy of haar innerlike oortuigings uit die prentjie. Mense word gereduseer tot 'n reeks dade. Dit staan teenoor die Nuwe-Testamentiese siening dat die self en dade mekaar wedersyds beïnvloed (vgl Mk 9:43-48). Die hele self is betrokke by die daad en die self het die vermoë om gedrag te verander. In Matteus 7:17-18; 12:33-35; 23:26 sê Jesus dat 'n goeie boom nie slegte vrugte dra nie. As die hart vol liefde is, sal die dade wat daaruit voortvloei nie boos wees nie. Met hierdie teenargument stel Via (2003:20) dit dat, hoewel die beginsel nie verabsoluteer kan word nie, die innerlike oortuiging en houding van mense in ' $n$ homoseksuele verhouding wel van belang is, aangesien dit die dade bepaal. Die tradisionele standpunt verteenwoordig 'n keuse om die reël te verabsoluteer en die literêre en sosio-historiese konteks te ignoreer. Via (2003:20-21; vgl Outka 1972:94, 103, 114-116) bespreek vier hermeneutiese opsies wat sowel Bybelse reëls as kultuurkontekste in ag neem, wanneer etiese beslissings geneem word:

- $\quad$ Reëls verloor hulle geldigheid wanneer die konteks verander.

- Reëls is nuttig, maar as daar konflik is tussen die reël en die konteks, kan weggedoen word met die reël.

- $\quad$ Indien daar konflik is, behoort die reël nie summier verwerp te word nie. As sekere etiese waardes in die konteks swaar genoeg weeg, kan die reël ter syde gestel word.

- $\quad$ Niks uit die konteks kan swaar genoeg weeg om 'n reël wat 'n daad verbied omdat dit immoreel is, ter syde te stel nie.

Die laaste moontlikheid is die uitgangspunt van die objektiewe en die voorlaaste dié van 'n dialektiese Skrifverstaan. Die bekende NuweTestamentiese etikus, Richard Hays (1996:381-382, 389-391) verdedig die tradisionele standpunt in sy boek, The moral vision of the New Testament. Hy wys uit dat die Skrif homoseksualiteit konstant en onvoorwaardelik afwys en die heteroseksuele huwelik sien as die enigste regverdigbare vorm waarbinne menslike seksualiteit uitgeleef mag word.

Hierdie standpunt neem egter nie in ag dat huweliksvorme bepaal word deur veranderende kulturele konvensies nie. In die Bybel kom ten minste drie 
tipes huweliksvorme voor. Hulle het oor 'n tydperk van meer as 12 twaalf eeue ontstaan en verander (kyk Van Aarde 1997-1998:345-355, 96-114). Vandag bestaan nie een van hierdie Bybelse huweliksvorme meer in die Westerse wêreld nie. Die rede waarom hedendaagse Westerlinge trou, naamlik wedersydse liefde, was nie die rede vir huweliksluiting in die NuweTestamentiese tyd nie. Familiehoofde het met mekaar onderhandel oor huweliksluiting tussen hulle kinders ter wille van familiebelange. Dit is dus problematies om die Bybelse huwelik van man en vrou te sien as die enigste moontlike ruimte waarbinne wedersydse liefe en seksualiteit uitgeleef kan word.

\section{2 'n Subjektiewe Skrifverstaan}

Volgens 'n subjektiewe eksegetiese benadering is homoseksuele gedrag nie onversoenbaar met die Skrif nie. Die Bybel word in hierdie benadering steeds ernstig geneem. Volgens hierdie verstaan van die Bybel verwys die NuweTestamentiese gedeeltes na pederastie, prostitusie of heteroseksuele perversiteit (of 'n kombinasie van die drie) en nie na 'n liefdevolle verhouding tussen mense van dieselfde geslag nie (kyk Waetjen 1996:103-116, Martin 1996:117-136). Of sulke verhoudings in die Bybelse tyd bestaan het, is onbekend, maar hulle bestaan wel vandag. Diegene wat "onreinheid" binne die reinheidsisteem van die Bybelse kulture nie meer gelyk stel aan "sonde" of "sondigheid" nie, soos byvoorbeeld Countryman (1988), val ook in hierdie groep eksegete. Mense wat die Bybel op hierdie manier benader, sien versoenbaarheid met die Skrif nie as die enigste kriterium vir geldige etiek nie. 'n Letterlike verstaan van die Bybel is in die verlede byvoorbeeld gebruik om slawerny en die uitsluiting van vroue uit die ampte te regverdig. Soos wat die kerk by slawerny en die onmenswaardige behandeling van vroue verby beweeg het, het dit nou tyd geword om ook verby te kom by 'n letterlike interpretasie van die Bybel waarmee vooroordeel geskep word teen homoseksuele mede-gelowiges (Doe 2000:44-45).

\section{3 'n Dialektiese Skrifverstaan}

\subsubsection{Die hermeneutiese boog}

Wanneer tekste geïnterpreteer word, is twee kontekste ter sprake: eerstens die literêre en sosio-historiese konteks van die teks, en tweedens die godsdienstige, intellektuele en kulturele konteks van die hermeneut/eksegeet (vgl Ricoeur [1986] 1991). Dit sluit in die persoon se voorverstaan, vooronderstelling en sosiale milieu (vgl Via 2003:2-3). Objektiewe 
Skrifinterpretasie is nie moontlik nie. Alle teoloë kom met hulle eie konteks, verstaan en vooroordele na die Bybel toe.

'n Ander belangrike beginsel vir die interpretasie van die Bybel is dat die kanon 'n ryk en diverse - soms teensprekende - horison bied waarteen individuele tekste verstaan behoort te word. Tekste het verskillende betekenisse binne verskillende kontekste. Hulle bedoel nie noodwendig wat hulle sê nie. Die horison verskaf die parameters vir 'n meer uitgebreide verstaan van die teks en dit bied ook meerdere toepassingsmoontlikhede. Verder kan dit wees dat die breër kanonieke konteks reëlreg teen 'n spesifieke teks kan ingaan. Die vraag is altyd of 'n spesifieke teks inpas by die breër konteks van die Bybel as geheel. Dit sal daartoe lei dat sommige Bybeltekste onaanvaarbaar kan wees in die lig van die betekenis van die evangelie as geheel.

Die eie kulturele konteks van die interpreteerder behoort ook in ag geneem te word. ' $n$ Vraag is byvoorbeeld hoe die onomwonde veroordeling van homoseksuele dade in sekere Bybeltekste harmonieer met wat geleer kan word van die sosiale wetenskappe en van die ervaring van homoseksuele Christene.

\subsubsection{Ou-Testamentiese getuienis}

Die Ou-Testament bied nie gronde vir 'n Christelike etiek wat homoseksualiteit as sodanig veroordeel nie. Die rede hiervoor is dat "homoseksuele" gedrag in die Ou Testament kultureel bepaal is. Dit blyk uit die volgende aspekte wat in die Ou Testament aangetref word:

- $\quad$ Homoseksuele dade maak mense onrein. Onreinheid het tot gevolg dat mense uitgesluit word van sosiale interaksie met ander en om in God se teenwoordigheid te kom. Reinheid is 'n belangrike kategorie in die Ou Tesamentiese wetstekste. Dit kom nie net by Israel voor nie. Dit is 'n pre-rasionele vooronderstelling wat nie in die Skrif self teologies gefundeer word nie. Ook die wettiese uitsprake oor oordeel en straf vir homoseksuele dade in die Ou Testament is kultureel bepaal.

- $\quad$ In 'n patriargale samelewing bedreig homoseksuele gedrag die noodsaaklike voortbring van manlike erfgename (Melcher 1996:93-99).

- $\quad$ Met dieselfde manlike geslagsorgaan wat die teken van die besnydenis dra (simbool van om aan God se volk te behoort), pleeg die persoon 'n onrein daad wat hom niks beter as 'n onbesnede heiden maak nie (Lev 18:3, 24, 27) (Bird 2000:151-152). Die etiek van Ou-Testamentiese Israel is in 'n sekere sin "'n etiek van genitalië" (Halperin 1990:24). 
- $\quad$ In 'n patriargale samelewing tas homoseksuele gedrag manlike eer aan. Vir ' $n$ man om in die posisie van die passiewe ontvanger (die een wat gepenetreer word) te wees, is oneervol vir alle mans. Daarom moet mans ander mans ten alle koste teen so 'n skande en vernedering beskerm. In die verhaal van die Leviet en sy byvrou (Rigters 19) is dit ten koste van die gasheer se dogter, 'n maagd wat deur haar pa uitgestuur word om verkrag te word, en die beskerming van die Leviet teen hierdie "gruwel" het die lewe van die sy byvrou gekos (vgl Bird 2000:137). Dit is ' $n$ eeu-oue siening. Die kerkvader Chrysostomos noem homoseksualiteit byvoorbeeld "erger as hoerery" omdat dit ' $n$ man tot 'n vrou maak (Edwards 1984:26).

Wanneer hierdie Ou-Testamentiese getuienis gebruik word om homoseksualiteit te veroordeel, het kultuurkonvensies gebou op 'n "etiek van genitalië", die Christelike etiek bepaal.

\subsubsection{Nuwe-Testamentiese getuienis}

As daar in die kanon teologiese of etiese konflik bestaan, kan Christene nie anders nie as om te besluit waaraan hulle prioriteit wil verleen. Via (2003:10) oefen sy persoonlike keuse soos volg uit: "I choose Paul and the Gospels over Leviticus as having the more profound understanding of the human situation."

In Markus 7 kritiseer die Fariseërs Jesus omdat die dissipels eet met onrein hande. Hulle het nie die voorgeskrewe rituele wassing nagevolg nie. Jesus se reaksie is dat wat fisies is nie kan onrein maak nie. Dit het geen effek op die hart nie. Die hart is die sentrum van die verhouding tot God, dus kan fisiese onreinheid nie die verhouding met God affekteer nie. Wat die hart onrein maak, naamlik slegte bedoelings en dade, kan wel in die pad kom van 'n goeie verhouding met God. Jesus beskou nie die Ou-Testamentiese kategorie van reinheid as geldig nie. Onreinheid is nie die gevolg van fisieke besoedeling nie. Dit is wanneer die wil van die mens nie in harmonie is met God se wil nie. Volgens Markus herinterpreteer Jesus onreinheid in persoonlike, intensionele en etiese terme (Via 2003:9). In die GrieksRomeinse konteks waarin Paulus hom bevind het, was daar nie-Christelike moraliste wat homoseksualiteit verdedig het and ander wat dit teengestaan het (vgl Scroggs 1983, 44-65; Furnish 1979:62-66). Paulus se etiese beskrywing van homoseksuale verhoudings stem ooreen met die van die nieChristelike teenstanders. Paulus verklaar verhoudings tussen dieselfde geslag tot onrein (Rom 1:24), maar hy bedoel duidelik onreinheid in die sin van sonde en nie in die sin van Ou-Testamentiese reinheid nie. Vir hom is die oorsaak 
van homoseksuele gedrag oormatige wellus wat hy aan heidense godsdienstigheid toeskyf (bv tempelorgies in die Grieks-Romeinse godsdienste).

Mense wat booshede pleeg, soos onsedelikes, afgodsdienaars, egbrekers en kwaadpraters word in dieselfde asem genoem as die wat homoseksuele dade pleeg. Sulke sondelyste is nie uniek aan die Christelike etiek nie (vgl Beukes 2003). Dit is 'n tipiese literêre vorm in die HellenistiesSemitiese moraalfilosofie. Die booshede is nie in 'n spesifieke volgorde gerangskik nie. Die funksie van so 'n lys was om algemene ontaarding te beklemtoon (vgl Geyser 2002:1669). Mense wat homoseksuele dade pleeg (malakoi en arsenekoital) word deur Paulus gemaan dat 'n gesindheid en optrede wat ander ontmenslik, nie te rym is met die waardes van God se koninkryk nie. Dit is met ander woorde nie iemand se mens-wees (in Paulus se taal die sarkikos-bestaan, bv die werklikheid van homoseksualiteit) nie, maar dat hulle op ' $n$ manier leef waar hulle nie deur God se Gees gelei word nie, wat veroorsaak dat hulle hulle buite God se koninkryk bevind. Herman Waetjen (1996:110) verduidelik dit soos volg:

In view of the other types of individuals that are named alongside the malakoi and arsenekoitai, it seems doubtful that Paul is excluding both youth and adult male from participating in the rule of God on the basis of the stipulation of the purity code of Leviticus 18 and 20. Rather, all of them - prostitutes, adulterers, thieves, greedy people, drunkards, abusive persons and swindlers, as well as "soft ones" and their adult male lovers - engage in activities that are destructive to the humanity of others or themselves. All of them are either victimized, dominating and exploiting others, or victims who for one reason or another allow themselves to be dominated and dehumanized. As long as they continue in their injustice, oppression and enslavement, they are incapable of receiving the gifts that the rule of God imparts: transcendence into freedom, possibility, and the fullness of life.

Die tema van die Romeine-brief is die herstel van die regte verhouding met God op grond van God se genade, soos wat dit geopenbaar is in die Christusgebeure. "God het almal aan die ongehoorsaamheid oorgegee, sodat God aan almal genade kan betoon" (Rom 11:32). Die uitspraak oor "teennatuurlike" seksuele omgang maak nie deel uit van die vermanende gedeelte in die brief aan die Romeine nie. Dit begin by hoofstuk 12 (vgl Beukes 2003). Dit gaan hier nog nie oor voorskrifte nie. Paulus meld "homoseksualiteit" in die verbygaan as deel van ' $n$ tradisionele lys wat sekere gedrag, waarskynlik onder andere pederastie (kyk Germond 1997:226-227; Doe 2000:39), afkeur. 
Romeine 1:26-27 is belangrik omdat die homoseksuele daad hier beskryf word en sulke dade onder vroue ook veroordeel word. Romeine 1:18-3:20 verduidelik waarom die boodskap van genade noodsaaklik is. Eerstens word gewys hoe erg die mens se verdorwenheid is. Volgens Paulus se argument het die nakoming van die wet nie gehelp om Israel in die regte verhouding met God te bring nie. Dieselfde geld vir die heidene. Ook die nakoming van hulle gebruike kan hulle nie in die regte verhouding met God bring nie. Die heidene het God se genade net so nodig soos Israel (vgl Germond 1997:227; Van Zyl 2002:254). Die hele inleidende gedeelte van Romeine bring die boodskap dat mense hulle nie uit eie krag met God kan versoen nie. Almal is sondig en daarom is God se genade onontbeerlik. Pederastie was deel van die heidene se sosio-religieuse lewe wat, soos Israel se "werke van die wet", lei tot dood. Pederastie was deel van afgodediens waar verganklike beelde aanbid is in plaas van die ware en lewende God (Rom 1:23, 25). Pederastie was 'n voorbeeld van heidene se lewe sonder God. Mense wat sonder God wil lewe, word oorgegee aan hulle eie dwaasheid en die slegte begeertes van hulle hart. Pederastie was vir Paulus die manifestasie van 'n "teen-natuurlike" lewe, 'n lewe sonder God. Diens aan afgode gaan in teen God se bedoeling met die mens. Liefde vir mekaar is die kern van 'n lewe wat versoen is met God. Pederastie veroorsaak die vernietiging van mense en is nie die gevolg van goedheid wat kom uit God se liefde nie.

Soos Christus se liefde die "einde van die werke van die wet" vir Israel beteken, is dit ook die einde van die selfvernietigende lewe van heidene. Romeine 1:26-28 is die teks wat volgens die tradisionele eksegese homoseksualiteit die sterkste afkeur. Die vraag is egter of ' $n$ mens vandag dieselfde teologiese afleiding kan maak as wat Paulus met pederastie gemaak het. Die mense waarna Paulus verwys, het bewustelik sonder God probeer lewe. Alle mense is by God welkom, ongeag hulle fisiese omstandighede. Jesus se insluiting van uitgeworpe mense in die koninkryk van God bevestig dat God nie voorkeur gee aan mense met 'n spesifieke sarkikos-bestaan nie. Die "waarheid van die evangelie" is dat die sarkikosbestaan nie die belangrikste is nie, maar dat die mens as sarks deur God se Gees beheers word.

Coleman (1989:84) verwys soos volg na Paulus se dialektiek tussen sarks en pneuma: "The Christian, indwelt by the spirit, has an intimate relationship with Christ, and he takes the view, against the agnostics, that human flesh and spirit are so interdependant that they must be regarded as, in effect, a unity." Die pneumatiese mens hou egter nie op om as sarks te bestaan nie. Net so is die skepping nie opgehef toe God dit op grond van Jesus Christus se dood en opstanding herskep het nie. 


\section{DIE KERKLIKE TRADISIE, DIE “GOD-BEDOELDE” HUWELIK EN DIE “BODY FIT” NATUURTEOLOGIE}

Op grond van sy interpretasie van die Bybelse materiaal, meen die NuweTestamentiese etikus, Richard Hays (1996), dat homoseksuele Christene selibaat behoort te lewe. Die kerk kan dus nie homoseksuele verhoudings inseën nie. Aan die ander kant, meen hy, behoort die kerk die menseregte ten opsigte van homoseksuele persone te ondersteun en hulle saam met ander sondaars in die kerk te verwelkom. Homoseksuele persone wat hulle weerhou van seksuele gedrag, behoort deur die kerk in die ampte toegelaat te kan word. Hays (1996:400-404) meen ook dat homoseksuele Christene hulle identiteit behoort te "hervorm" aan die hand van die evangelie. Hy is daarvan oortuig dat verandering moontlik is. Homoseksualiteit is dan soos alkoholisme. lemand kan 'n alkoholis wees maar nie drink nie omdat dit skadelik is vir die persoon. So is homoseksuele gedrag dan ook skadelik vir die persoon wat dit beoefen.

Met 'n soortgelyke bedoeling as Hays, behandel Robert Gagnon in sy boek, The Bible and homosexual practice, al die Bybeltekste wat direk of indirek verwys na homoseksuele gedrag asook die tersaaklike NabyeOosterse en Griekse tekste. Verder neem hy die resultate van hedendaagse sosiaal-wetenskaplike, psigologiese en teologies-etiese ondersoeke in ag. Die doel van sy boek is tweeledig: om homoseksuele gedrag te definieer as sonde en om aan te dui dat geen gegewens uit die milieu van die Bybel of die hedendaagse konteks enigiets kan bydra om die Bybelse standpunt teen homoseksualiteit omver te werp nie (Gagnon 2001:37, 341-493).

Indien Hays en Gagnon se aanname getoets word aan hedendaagse sosio-psigologiese insigte en kennis, kan aangetoon word dat homoseksuele gedrag op sigself nie skadelik is vir mense nie, mits dit wederkerig is, met albei se instemming en in 'n liefdevolle, toegewyde verhouding. Hoewel promiskue homoseksuele gedrag wel skadelik vir mense - fisies sowel as psigies (kyk Gagnon 2001:471-476) - kan homoseksualiteit op sigself nie in Pauliniese terme beskou word as "sondig" as dit nie "skadelik" is nie.

Benewens die duidelike standpunt van die Bybel dat homoseksuele gedrag sonde is, is daar ook nog die argument dat dit teen die natuur is. Dit is 'n saak waarop die uitdrukking "teennatuurlikheid" in Romeine betrekking het. Homoseksualiteit is teen God se ontwerp vir die verhouding tussen die geslagte. God het die ontwerp geopenbaar en in die Skrifte bekend gemaak. Dit kom op 'n sigbare manier tot uitdrukking in die skepping van man en vrou en is verwring deur die sondeval. "Die natuur" gaan hier oor die passing van die manlike penis in die vroulike vagina, gepaardgaande met die funksie van 
prokreasie en die geleentheid tot wedersydse plesier en stimulasie. Seks tussen mense van dieselfde geslag gaan in teen die andersheid wat deel is van God se ontwerp (Gagnon 2001:40-41, 138-142, 254-262, 380, 392; contra Via 2003:26). Derhalwe behoort homoseksuele praktyke onvoorwaardelik verwerp te word, volgens Gagnon.

Die sogenaamde anatomiese "body fit" argument was egter in die Mediterreense wêreld ingebed in die kulturele reinheidsmaatreëls waaroor onder andere die heiligheidskodes in Levitikus praat. Volgens die reinheidsideologie kon wat in liggaamsopeninge ingaan, soos onrein kos in die mond, 'n mens onrein maak. So is alles wat uit liggaamsopeninge uitgaan ook onrein, omdat dit uit plek is (wat in die liggaam hoort, is buite die liggaam). Aanraking daarmee maak 'n mens onrein (kyk Neyrey 1988a:63-92; 1988b:72-82; 1990 oor die rein en onrein implikasies van liggaamsopeninge in die Meditereense wêreld). Teenoor so 'n "natuurteologie", koppel Jesus 'n rein lewe voor God nie simbolies aan die uiterlike menslike anatomie nie, maar aan geloof in die hart (Mark 7). Paulus se etiese riglyne word ook bepaal deur die eskatologiese werklikheid van die heilsame teenwoordigheid van God, 'n "nuwe skepping" (natuur) wat ingelui is deur die opstanding van Jesus. "Of 'n mens besny is of nie, is nie van belang nie, maar dat jy 'n nuwe mens is. En almal wat volgens hiedie beginsel leef, die ware Israel [van God] - mag God aan hulle vrede gee en barmhartigheid bewys" (Gal 6:15-16). Besnydenis of nie, rein of onrein, (insluitende die dinge van die natuur soos saad en liggaamsopeninge soos mond, anus, penis en vagina) en ander dualismes van die reinheidssisteem, is vervang met die "bediening waardeur die mense vrygespreek word" en dit oortref die ou bedeling verreweg in heerlikheid (2 Kor 3:9). Reinheidsisteme wat die wêreld verdeel in binêre opposisies van heilig en onheilig is oorstyg (Waetjen 1996:110). Die kerk kan dus nie eties 'n saak hê teen nie-promiskue en nie-skadelike orale seks nie. Of Paulus ook aan hierdie aspekte gedink het toe hy sy brief aan die Romeine geskryf het, weet ons nie. Maar sy siening dat besnydenis of nie, nie voorwaarde vir geloof is nie, het hierdie implikasies.

In die antieke Mediterreense wêreld is alle relasies verstaan in terme van kategorisering op grond van manlike en vroulike vorme. Dit geld vir mense, diere en selfs iets soos taalvorme. Dit is op 'n natuurteologiese manier gesien as 'n Goddelike skeppingsorde en dit is hoe die mense in die Bybelse tyd georganiseer is in hulle kultuur. Wie of wat nie daarby inpas nie, is teen die wil van God. Om 'n mens se identiteit te vind in een van die rolle en streng binne die rol te bly, het in die hedendaagse tyd verval en kan nie langer as normatief voorgehou word nie. "Their validity has been canceled once and for all by the paradigm shift that has occurred in the last 150 years" (Waetjen 
1996:112). Seksuele identiteit en geslagsrolle word nie meer gedefinieer op grond van genitalie nie. Seksualiteit het eerder geword tot "a principle of the self" (Halperin 1990:24). "Sexuality is thus the inmost part of an individual human nature. It is the feature of a person that takes longest to get to know well, and knowing it renders transparent and intelligible to the knower the person to whom it belongs. Sexuality holds the key to unlocking the deepest mystery of the human personality: it lies at the center of the hermeneutics of the self" (Halperin 1990:26).

Geen van die tekste uit die twee Testamente van die Bybel wat gaan oor afwykende seksuele gedrag het direk betrekking op wat vandag "homoseksualiteit" genoem word nie. Die woord "homoseksueel" is eers onlangs (1892) gemunt om 'n hedendaagse sosio-kulturele konstruk van seksualiteit te beskryf. Die woord "heteroseksueel" het agt jaar later op die toneel verskyn. Reinheids-kodes en die etiese norme wat met hulle gepaard gegaan het, is nie langer geldig nie. "Homoseksueel" wat vroeër as "onrein" beskou is in opposisie tot "heteroseksueel" wat as "rein" gesien is, kan nie langer gehandhaaf word nie. "Given the realities of sexuality as conceptualized, experienced, and institutionalized human nature, both homosexuality and heterosexuality may be represented in the body of Christ, the new creation of the One and the Many. This implied, of course, that both are subject to the ethical norms of God's rule and therefore are expected to give embodiment to the new humanization that makes it possible" (Waetjen 1996:113). Die doopformule in Galasiërs 3:28 toon aan hoe binêre opposisies opgehef is in die nuwe bedeling: "Dit maak nie saak of iemand Jood of Griek, slaaf of vry, man of vrou is nie: in Christus Jesus is julle almal één." Vandag word mense nie gesien as geslagstipes op grond van hulle genitalië nie. Die self word onder andere gekonstitueer deur 'n persoon se geslagtelikheid en daaraan word uitdrukking gegee in "a wide range of human behaviors, attitudes, tastes, choices, gestures, styles, pursuits, judgments and utterances" (Halperin 1990:26).

Via (2003:36) stel die skerp vraag of, wanneer die tradisionele kerklike standpunt homoseksualiteit veroordeel, mense se welsyn voorop staan en of hulle nie eerder beskadig word nie. Hy meen dit is noodsaaklik om te luister na homoseksuele mense se ervaring. Daar is praktiserende homoseksuele Christene wat geen spanning ervaar tussen die twee aspekte van hulle lewens, hulle geloof en die uitlewing van hulle seksualiteit, nie (Bird 2000:143). 'n Homoseksuele Nuwe-Testamentikus, Dale Martin (1996:130131) stel dit soos volg: 
Any interpretation of scripture that hurts people, oppress people, or destroys people cannot be the right interpretation, no matter how traditional, historical, or exegetically respectable. There can be no debate about how the fact that the church's stand on homosexuality has caused oppression, loneliness, self-hatred, violence, sickness, and suicide for millions of people. If the church wishes to continue with its traditional interpretation it must demonstrate, not just claim, that it is more loving to condemn homosexuality than to affirm homosexuals ... Is it really better for lesbian and gay teenagers to despise themselves and endlessly pray that heir very personalities be reconstructed so that they may experience romance like their straight friends? Is it really more loving for the church to continue its worship of "heterosexual fulfillment" ... while consigning thousands of its members to a life of either celibacy or endless psychological manipulations that mas-querade as "healing"?

Martin stel verder dat baie homoseksuele mense nie siek of pervers of selfs "effeminate" is nie, maar lief raak vir iemand van dieselfde geslag. Volgens hom word homoseksuele mense beskadig nie deur hulle homoseksualiteit nie, maar wel in die proses van probeer ontken wie hulle is - wat lei tot sarkofobie.

\section{DIE "TEORETIESE” WETENSKAPLIKE REDE}

\subsection{Wetenskaplik verklarings vir die oorsake van homoseksuele oriëntasie}

In die prehistoriese tyd was mense se lewensverwagting kort - 30 jaar of minder (kyk Simons 1989:1343-1350; Smith 1993:11), vir die eerste duisend jaar van menslike bestaan miskien selfs so laag as 15-17 jaar (Smith 1993:12). Self teen die $16 \mathrm{e}$ tot $18 \mathrm{e}$ eeu was mense se lewensverwagting steeds in die omgewing van 30 jaar, hoewel mense wat tot daardie ouderdom oorleef het, 'n goeie kans gehad het om baie oud te word (kyk Vinovskis 1971:579-590; Laslett 1985:199-230). In die lig hiervan was voortplanting nie net belangrik nie, maar lewensnoodsaaklik vir die voortbestaan van die menslike samelewing. Seksuele gemeenskap wat nie sou uitloop op die geboorte van kinders nie, sou skadelik wees vir die samelewing. Semen was gesien as "beperkte middele" ("limited goods") en in Israel het prokreasie die voortgang van "heilige saad" beteken (kyk Malina [1981] 1993:137-138). Kerkvaders het die belangrikheid van kindergeboorte verwoord. "Die kind is die enigste rede vir 'n vrou om te trou", is die uitspraak van Ambrosius (in Erdokimov 1985:22) en volgens Augustinus (in Hunter 1992:120-121): "The good of marriage ... among all nations and peoples lies in the purpose of procreation and in faithful preservation of chastity." Soos masturbasie, 
ondermyn mans se homoseksuele gedrag hierdie lewensreël. Hierdie kulturele konvensie plaas masturbasie en homoseksuele praktyk op dieselfde vlak.

Volgens bioloë, wat geïnteresseerd is in wortels van seksuele gedrag, is min inligting oor prehistoriese seksuele gedrag beskikbaar. Hulle meen egter dat die vroegste mense sekere seksuele gedrag vertoon het wat vandag as "homoseksueel" sou deurgaan (kyk Taylor 1996:80-81). Taylor (1996) wys op goed gedokumenteerde getuienis van homoseksuele aktiwiteit onder van die groot aapsoorte. Taylor (1996:182) verwys na die vroegste skriftelike getuienis van menslike seksualiteit: "As soon as there were written records, from around 5,000 years ago in the Near East, we find references to many of the sexual practices - homosexuality, male and female transsexualism and transvestitism, masturbation - familiar to us today." Hy stel ook dat homoseksuele aktiwiteit algemeen voorgekom het in Middeleeuse kloosters (Taylor 1996:222).

Aangesien heelwat argumente ten opsigte van homoseksualiteit gevoer word op sterkte van biologiese oorwegings, is dit nodig om te vra of biologie enige bydrae kan lewer. Volgens Alice Ogden Bellis \& Terry Hufford (2002:16) is biologiese data nie baie wyd beskikbaar nie en wat daar is, lyk soms teensprekend. Daarom behoort dit versigtig en krities geëvalueer te word. Die vrae aan die orde is: Is homoseksualiteit 'n keuse of 'n biologiese gegewene (geneties)? Is dit aangeleerde gedrag of geneties? Is dit die gevolg van omgewingsinvloed of geneties? Indien dit 'n gedragsgenetiese oorsprong het, behoort dit beskou te word as "abnormaal" of net as 'n alternatiewe uitdrukking van seksualiteit?

\section{2 'n Biologiese perspektief}

Op grond van genetiese navorsing en die studie van hormone (Bellis \& Hufford 2002:17-41), meen Burr (1996:14-15) dat mense óf homoseksueel óf heteroseksueel is, soos wat mense linkshandig of regshandig is. Hy beskou biseksualiteit as aangeleerde gedrag. Nie alle wetenskaplikes stem hiermee saam nie. Omdat navorsing dui op 'n gedragsgenetiese oorsprong en nie slegs biologies-geneties nie, kies baie wetenskaplikes eerder vir 'n kontinuum van gedragsuitinge vanaf sterk heteroseksueel aan die een kant tot sterk homoseksueel aan die ander kant.

Hoewel biologies-genetiese oorsake 'n rol speel, dui studies aan dat daar altyd wel 'n element van invloed van die omgewing teenwoordig is en nie alles aan gene toegeskryf kan word nie. ' $n$ Voorbeeld hiervan is dat een lid van 'n identiese tweeling homoseksueel kan wees en die ander nie. Gene bepaal nie die ontwikkeling van gedragseienskappe nie. Eksterne en interne 
omgewingsfaktore kan sowel die uitdrukking daarvan as die graad van uitdrukking bepaal. Gedragsgenetika word egter selde bespreek in die biologiese ondersoek na homoseksualiteit (Bellis \& Hufford 2002:37).

\section{3 'n Sosiaal-wetenskaplike perspektief}

Benewens die biologiese navorsing het psigiaters, psigoloë en sosioloë reeds indringend ondersoek gedoen na die aard en gevolge van homoseksualiteit. 'n Gevolg van die navorsing is onder andere dat die American Psychiatric Association (APA) in 1973 homoseksualiteit verwyder het van die amptelike diagnostiese handboek, die DSM II. Navorsingsresultate het aangetoon dat homoseksualiteit nie voldoen aan die kriteria om geklassifiseer te word as 'n geestessiekte of gereken kan word as 'n morele afwyking nie (kyk Ellison 1993:163). Geen spesifieke psigososiale of gesinsdinamieke kon nog geïdentifiseer word as die oorsaak van homoseksualiteit nie, selfs nie eens kindermolestering nie (APA 2000:1; vgl Bellis \& Hufford 2002:42). In 'n onlangse publikasie van die APA oor homoseksualiteit en biseksualiteit word gestel dat geen wetenskaplike ondersoek kon aantoon dat enige terapie om seksuele oriëntasie te verander, effektief is nie (A P A 2000:4).

\subsection{Sosiale en religieuse stigmatisering}

In 1992 het die APA (2000:2) die volgende verklaring ten opsigte van die stigmatisering van homoseksuele persone uitgereik:

Whereas homosexuality per se implies no impairment in judgment, stability, reliability, or general social or vocational capabilities, the American Psychiatric Association calls on all international health organizations, and individual psychiatrists in other countries, to urge the repeal in their own country of legislation that penalizes homosexual acts by consenting adults in private. And, further, the APA calls on these organizations and individuals to do all that is possible to decrease the stigma related to homosexuality wherever and whenever it may occur.

Volgens die APA is homoseksulaiteit 'n manier waarop 'n minderheidsgroep menslike liefde en seksualiteit uitdruk (Ellison 1993:165). Navorsing het uitgewys dat homoseksuele persone in alle opsigte net so goed sosiaal funksioneer as heterosekuele persone. Homoseksualiteit is ook nie ' $n$ kwessie van persoonlike keuse nie. Die homoseksuele oriëntasie word vroeg in die lewenssiklus aangetref, moontlik selfs voorgeboortelik. Dit raak ongeveer $10 \%$ van die bevolking - 'n persentasie wat konstant bly oor tye en kulture heen, ten spyte van die morele waardes van verskillende gemeenskappe. Homoseksualiteit neem nie toe (of af) as morele kodes of sosiale mores 
verander nie. "Research findings suggest that efforts to repair homosexuals are nothing more than social prejudice garbed in psychological accouterments" (Conger 1975:620-651).

In die wêreld en ook in Suid-Afrika word homoseksualiteit toenemend aanvaar. In die kerk is dit egter steeds ' $n$ taboe onderwerp. (Kyk Anthonissen \& Oberholzer [2001] vir 'n uitstekende uiteensetting van die debat in SuidAfrika en die NG Kerk in die besonder. Die werk van die praktiese teoloog, Merton P Strommen [2001] is van soortgelyke gehalte en illustreer die situasie in Noord-Amerika.) Cameron-Ellis (1999) se psigologiese navorsing aan die Universiteit van Pretoria het gefokus op die negatiewe invloed van die kerk ten opsigte van homoseksualiteit en hoe die kerk eerder 'n positiewe rol sou kon vervul. Sy het bevind dat homoseksuele persone gewoonlik net welkom is in die kerk as hulle stilbly oor hulle homoseksualiteit of verander (CameronEllis 1999:1). Die nuwe Suid-Afrikaanse Grondwet van 8 Mei 1996 bepaal dat daar nie gediskrimineer mag word teen iemand op grond van seksuele oriëntasie nie. Suid-Afrika is die eerste land in die wêreld wat so 'n klousule in die grondwet het. Dit is opvallend dat die een politieke party wat beswaar gemaak het teen die insluiting van die klousule, die Afrika Christen Demokrate was (kyk Cameron-Ellis 1999:2).

Sigmund Freud se siening van homoseksualiteit het daartoe bygedra dat dit in die verlede beskou is as 'n siekte. Freud het dit gesien as beskadigde of geblokkeerde heteroseksualiteit (kyk Coleman 1980:13-15). Die ontstaan van die skade was êrens tussen die ouderdomme van vier en nege jaar. Volgens Freud gaan alle mense deur ' $n$ "homo-erotiese fase". Hierdie siening word egter nie langer aanvaar nie (kyk Coleman 1980:15-17). Volgens die Freudiaanse model vind die vorming van 'n identiteit en sosiale organisasie plaas wanneer homoseksuele begeertes onderdruk of gesublimeer word. In die post-Freudiaanse materialistiese model gaan dit nie oor die onderdrukking van begeertes nie, maar oor sosiale organisering op grond van psigologiese faktore (vgl o a Van den Aardweg 1985:183; Jones \& Yarhouse 2000a:54-60). Navorsing op hierdie gebied wat nog steeds 'n biologiese fokus het, "argue that sexual orientation appears to be a complex characterstic of multifactorial or heterogenous origin which probably involves a complex interaction between genetic, biological, experiental and socio-cultural factors" (Jones \& Yarhouse 2000b:104). Hierdie konstellasie van faktore lei tot 'n homoseksuele oriëntasie wat uitdrukking vind op maniere wat van een homoseksuele persoon tot ' $n$ ander verskil. Hoewel homoseksualiteit nie net die produk van gene is, soos die kleur van hare of oë nie, toon navorsing op die gebied van gedragsgenetika dat mense nie kan kies of hulle wil gay of nie (Jones \& Yarhouse 2000b:105). 
Homoseksuele orëntasie en gedrag wek homofobie in die samelewing. Dit het twee gevolge. Die samelewing kommunikeer (soms onbewustelik) weersin en selfs haat aan homoseksuele persone (vgl De Gruchy 1997:241242). Homoseksuele persone toon die neiging tot die onderdrukking van die self, neuroses en identiteitsverwarring (kyk Dollimore 1991:245). Die laaste word vererger deur die eerste. Die destabiliserende gevolge van homofobie in die lewens van homoseksuele persone en in die samelewing het tot gevolg gehad dat die houding in mediese en psigiatriese kringe verander het $(\mathrm{vgl}$ Kitzinger 1996:107). Die besluit van die APA om homosekualiteit uit die lys van die Diagnostic and Statistical Manual uit te haal (Cameron-Ellis1999:14), het 'n uitkringende effek gehad op wat as "abnormaal" beskou word. Homoseksualiteit kan gewoon gesien word as 'n aspek van sosialiseringservarings en nie as 'n "probleem" nie. 'n Verdere gevolg is dat die samelewing bewus geword het van die negatiewe rol van die stereotipering van homoseksuele persone as 'n sosiale proses (Cameron-Ellis 1991:16).

Stereotipering speel 'n groot rol in negatiewe persepsies en houdings ten opsigte van homoseksuele persone. Dit is ' $n$ bydraende rede tot gays se ervaring dat hulle deur groepe, soos byvoorbeeld die kerk, verwerp word. Navorsing toon dat hierdie stigmatisering en marginalisering van die belangrikste lewenskwessies van homoseksuele persone is. Die A P A het egter bevind dat daar geen onstabiliteit en gebrek aan oordeelsvermoë, betroubaarheid of algemene sosiale en beroepsgeskiktheid aan homoseksualiteit as sodanig gekoppel kan word nie (kyk Camron-Ellis 1999:16). Onbevange interaksie met homoseksuele persone kan inderdaad lei tot die afbreek van negatiewe stereotipering. Die Nuwe-Testamentikus David Balch (2000:301) verwys na so 'n ervaring van die hetereoseksuele Jodin van Los Angeles, Janet Marder, rabbi van die wêreld se eerste gaysinagoge:

[After five years of experience:] My attitude toward homosexuality has moved from uncertain tolerance to full acceptance. I see it now as a sexual orientation offering the same opportunities of love, fulfillment, spiritual growth, and ethical action as heterosexuality. I still do not know what "causes" homosexuality, but I must confess that at this point I do not much care - any more than I care about what "causes" some people to have a special aptitude for music and others for baseball. I simply accept with pleasure the diversity of our species.

(Marder 1989:213) 
Sosio-psigologiese bevindings (kyk Cameron-Ellis 1999:73) is onder meer die volgende: heteroseksuele persone se teologiese oortuigings verander wanneer hulle nader kontak het met homoseksuele persone; die kerk word beïnvloed deur die samelewing; homoseksuele persone ervaar innerlike konflik omdat hulle deur die kerk daarvan beskuldig word dat hulle ongehoorsaam is aan God se wil en dat hulle tradisionele familiewaardes vernietig (Cameron-Ellis 1999:62). Laasgenoemde het te doen met homofobie en sarkofobie wat deur die kerk versterk word. Dit veroorsaak dat homoseksuele persone die kerk nie as 'n tuiste kan eraar nie.

\section{DIE “PRAKTIESE” TEOLOGIESE REDE}

\subsection{Homofobie}

Die post-Freudiaanse visie op seksualiteit as 'n sosio-psigologiese verskynsel het bygedra tot homofobie. Dit beïnvloed hoe heteroseksuele persone gays negatief sien. Dit het ook tot gevolg dat gelowige gays 'n identiteitskrisis ervaar wat hulle verhouding met die institusionele kerk raak. Geloof word nie deur seksuele oriëntasie gewek of bepaal nie. Tog kan geloof nie los van emotiewe ervaring of die ervaring op grond van die alledaagse praxis gesien word nie (kyk Immink 2003:27-78). Homofobie het innerlike konflik tot gevolg - konflik tussen die self en Bybelse norme en tussen die self en kulturele konvensies wat óf die kerk óf die (post-Freudiaanse) menswetenskappe as normaal, aanvaarbaar en normatief tipeer. Homofobie lei by homoseksuele persone tot selfhaat (sarkofobie) en depressie vanweë die onderdrukking van seksuele behoeftes. Die negatiewe rol van die kerk ten opsigte van homofobie veroorsaak dat homoseksuele mense die kerk verlaat. Daarmee skaar hulle hulle by die baie ander gesekulariseerde mense wat seergemaak of ontnugter is deur die kerk.

\subsection{Sekularisering}

Pyn en wanhoop lê agter die vertrek van homoseksuele Christene uit die kerke. Baie van hulle se lewens het verarm met die verlies van hulle godsdienstradisie, die liefde van God en geloofsgemeenskap. Hulle kom voor die dilemma te staan: om in God te glo beteken om hulle eie homoseksualiteit te haat, en om hulle homoseksualiteit te aanvaar, beteken om die geloof in God te moet verwerp. Volgens die terapeut, John McNeill (1988:13), kom die deurbraak vir homoseksuele gelowiges "with the realization that God is not identical with any particular church." Vir McNeill is dit trouens die taak van elke gelowige om nie toe te laat dat die kerk 'n mens se geloof bepaal nie (soos die kerk as heilsinsituut in die Rooms-Katolieke Kerk). As iemand 
ontnugter raak met die feilbare, menslike kerk, hoef die persoon die geloof nie te verloor nie. Indien iemand as gevolg van die kerk se optrede die geloof verloor, is die kerk nie heeltemal vry te spreek nie. Die Franse gelowige en filosoof Gabriel Marcel (in McNeill 1988:13) stel dit soos volg: "The believer [in die kerk] must see him- or herself as someone responsible in a certain measure for the unbelief of the other ..." Vir homoseksuele persone om eerlik te kan sê en leef wie is, het hulle ' $n$ liefdevolle gemeenskap nodig waarbinne hulle wonde kan genees, hulle kan leer om hulleself te aanvaar, om hulle geestelike lewe en seksuele werklikheid te integreer, en om hulle geestelike lewe te laat gedy. Soos alle ander mense behoort hulle te kan leer om vreugde te vind in hulle seksualiteit en om hulle verhoudings te bedryf in die teenwoordigheid van God. Hulle het ook die ondersteuning van 'n gemeenskap nodig in die stryd teen ongeregtigheid (Mc Neill 1988:193).

\subsection{Gay-kerke}

Die bestaan van gay geloofsgemeenskappe dui daarop dat homoseksualiteit 'n lewensverskynsel is en ook dat gelowige homoseksuele nie tuis is in die gevestigde kerke nie. Sommige homoseksuele persone verlaat die kerk en verloor dikwels ook hulle geloof. Ander wat nie bereid is om hulle geloof prys te gee nie, kan nie anders as om hulle in aparte geloofsgemeenskappe te organiseer nie. Daar is drie gay kerklike gemeenskappe in Suid-Afrika: die Reformerende Kerk, die Deo Gloria groep en die Gay Christian Community (vgl Beukes 2003). Die Reformerende Kerk met ongeveer 350 lede is elf jaar gelede in Pretoria gestig. Die totale lidmaattal van die kerk is ongeveer ' $n$ duisend. Die Deo Gloria groep is vyf jaar gelede gestig. Hulle het van die Reformerende Kerk weggebreek om ' $n$ meer charismatiese gemeente te begin. Die Agalia Kerk in Centurion is ook 'n "wegbreekgroep" wat later weer aansluiting by die Reformerende Kerk gesoek het. Hulle bediening is meer charismaties as die Reformatoriese tradisie. Die Gay Christian Community in Johannesburg is die oudste en kleinste groep. Hulle lede kom uit 'n Afrika tradisie. Hulle het twee jaar gelede hulle naam verander van Gay Christian Community na Gay Christian Church.

Die bestaan van hierdie kerke wys duidelik dat homoseksuele persone soek na aanvaarding binne 'n geloofsgemeenskap en voor God. Hulle behoort hierdie aanvaarding te kan vind binne bestaande kerke. Die amptelike standpunte van die gevestigde kerklike kringe voed egter die opinie dat homoseksuele persone nie voor God aanvaarbaar is en daarom nie volledig in die kerk geakkommodeer kan word nie. Tog vind 'n klemverskuiwing stadig maar seker plaas deurdat die fokus weg van die verskynsel en meer op die mens geplaas word ( $\mathrm{vgl}$ Van Zyl 2002:250). 


\section{CHRISTELIKE ETIEK VANUIT 'N PASTORALE PERSPEKTIEF}

Die afgelope tyd is heelwat aandag gegee aan die sosio-kulturele kontekste van die Bybeltekste oor "homoseksualiteit". Die ondersoeke het uitgewys dat sommige tradisionele sienings nie so goed Bybels gefundeer is as wat gemeen is nie. Dit is veral die geval met morele uitsprake omdat moraliteit so afhanklik is van konteks. Die betekenis van menslike optrede kan alleen gevind word binne die konteks of situasie waarin dit plaasvind. So ook verskil die konsekwensies van mense se gedrag van situasie tot situasie. Dit beteken nie dat geen algemene morele uitsprake gemaak kan word nie. Dit beteken egter wel dat die toepassing van morele beginsels sal verskil in verskillende situasies.

Wanneer etiese perspektiewe verander as gevolg van konteks, verander dit nie die hart van die Reformatoriese geloof nie (sola fidel). As Skrifverstaan egter nie ruimte vir geloof bied nie, het 'n onhoudbare spanning tussen sola fidei en sola Scriptura ontwikkel. Vanuit 'n Reformatoriese perspektief sal die geloofsdimensie deel wees van die mens se ontmoeting met die Heilige Skrif as die lewende woord (teenoor die "dooie letters" van 'n objektiewe en fundamentalistiese Bybelgebruik) van God.

Nadat die kerk na al die teoreties-wetenskaplike en prakties-teologiese (insluitende die eksegetiese) argumente geluister het, moet ' $n$ besluit geformuleer word. Die volgende moontlikhede het na vore gekom in die Church of England se Lambeth Conference 1998 (kyk Doe 2000:Appendix 2):

- $\quad$ Die kerk behoort in die lig van die objektiewe lering van die Skrif vas te hou aan die getrouheid tussen man en vrou in die huwelik as lewenslange verbintenis en te verkondig dat seksuele onthouding die keuse moet wees van hulle wat nie tot die huwelik geroep is nie.

- Terwyl die kerk homoseksuele praktyk verklaar tot onversoenbaar met die Skrif, roep die kerk al die lidmate op tot 'n patorale bediening aan mense ongeag hulle seksuele oriëntasie. Die kerk veroordeel homofobie as ' $n$ irrasionele vrees vir homoseksuele persone, geweld in die huwelik, asook enige handeling wat die huwelik en seksualiteit ontheilig (bv die kommersialisering van seks).

- Hoewel kultuur-bepaalde uitsprake oor "homoseksuele" gedrag in die Bybel negatief is, erken die kerk dat daar vandag persone is wat hulleself ervaar as mense met homoseksuele oriëntasie. Baie van hulle is lidmate van die kerk is. As lidmate vra hulle van die kerk pastorale sorg en morele leiding. Hulle verlang na die lewendmakende krag van God se Gees om hulle lewens volgens God se wil in te rig. Dit sluit 
hulle verhoudings in. Die kerk onderneem om te luister na die ervarings van homoseksuele persone en hulle te verseker van God se liefde. Die kerk glo dat alle gedooptes, alle gelowiges ongeag hulle seksuele oriëntasie, volledig lede van die liggaam van Christus is.

Die ander moontlikheid word in hierdie artikel beredeneer. Dit is naamlik om in te stem met laasgenoemde gesindheid, met een verandering. Vanuit 'n dialekties-teologiese perspektief is dit nie nodig om Skrif-uitsprake oor "homoseksualiteit" as negatief te sien nie. Kultuur-bepaalde uitsprake in die Ou Testament is "hervorm" deur die evangelie van Jesus Christus soos veral die Nuwe Testament daaroor getuig. Volgens die evangelie is mens-wees as sodanig (sarkikos-bestaan) nie sondig nie. Sonde is om die heil te soek in mens-wees in plaas van in God.

Die evangelie het ook 'n etiese implikasie. Dit spruit voort uit hoe Jesus omgegaan het met sy volgelinge. Hy het ' $n$ groep toegewyde mense waarvan baie in hulle kultuur randfigure was, rondom Hom vergader. Vir homoseksuele mense bied dit die moontlikheid om ten spyte van hulle gemarginaliseerdheid in kerk en samelewing, tog ook toegewyde volgelinge van Jesus te wees. Oor waarom mense sou wou deel word van die Christelike gemeenskap, sê die Nuwe-Testamentikus van Harvard, Helmut Koester (in Hazel 2000:16) die volgende: "Certain parts of the early Christian mission were intent in creating a new community. Only for that reason was this movement successful ... There is a future for the individual." Gemarginaliseerde mense was welkom in die vroeë Christelike gemeenskap. In die gemeenskap was almal gelyk, liefde was die norm en sorg vir mekaar is beskou as belangrik. "People are taken out of an isolation ... Christianity really established a realm of mutual social support for the members who joined the church. So, Christianity could adjust to different types of people" (Koester, in Hazel 2000:16).

Volgens die godsdienssosioloog, Rodney Stark (in Hazel 2000:16) was 'n doel van die Christelike geloof altyd om 'n morele klimaat te skep binne die kultuur. Die klem lê op waardes soos genade: "Wees barmhartig soos Ek barmhartig is" (Luk 6:36). Omdat God die mensheid liefhet, kan mense God nie eer en dien as hulle mekaar nie liefhet nie - was 'n nuwe idee in die tyd van die Nuwe Testament. Selfs meer revolusionêr was die idee dat Christelike liefde en barmhartigheid betoon behoort te word ook aan mense buite die kringe van familie of volksgenote. Op grond hiervan soek homoseksuele mense aanvaarding binne Christelike geloofsgemeenskappe. Soos ook die geval was met Jesus se vroegste volgelinge, is vooroordele en moeilike Skrifgedeeltes egter struikelblokke wat verhinder dat randpersone onvoorwaardelik ingesluit word in die familie van God (Hazel 2000:16). 
Jesus het vir randpersone hoop gegee toe hulle binne die Israelitiese kultuur beskou is as onaanvaarbaar voor God en gelyk aan heidene. Jesus bring hoop deur 'n weg te wys vir mense om onvoorwaardelik in God se teenwoordigheid te lewe. Vir mense wat nie randfigure was nie, het Jesus presies dieselfde weg gewys. Randfigure word nie in God se koninkryk ingesluit omdat hulle randfigure is nie. Dit is nie 'n daad van insluiting op grond van humanitêre oorwegings nie. Die insluiting van randfigure wys dat God se liefde groter en anders is as dié van mense wat net voorwaardelik kan liefhê en diegene uitsluit wat volgens konvensie en kultuur as onaanvaarbaar gereken word. Die evangeliese boodskap van inklusiwiteit beklemtoon die genade van God. Mense leef alleen op grond van geloof en uit die genade. Dit gaan dus nie daaroor dat homoseksuele mense randfigure is en daarom deur die kerk aanvaar móét word nie. Die kerk aanvaar alle mense wat in Jesus Christus glo. Die evangelieboodskap is dat elke mens onvoorwaardelik met God versoen kan wees. Hierdie versoening word vir mense aangebied ongeag hulle fisiese (sarkikos-) omstandighede - dit geld vir homoseksuele en heteroseksuele persone. Alle gelowiges is gelyk voor God. As sommige gelowiges uitgesluit en die ander ingesluit word, is die vraag of die kerk uit die genade leef en of die kerk aan die "waarheid van die evangelie" gehoorsaam is.

Die oortuiging in die Hervormde Kerk is dat die eenheid van die kerk nie gaan oor institusionele eenheid as sodanig nie, maar oor die "eenheid van die waarheid" op grond van die belydenis. In Galasiërs 1:6-7 verwys Paulus na 'n "evangelie" wat "geen evangelie" is nie. Hierdie "geen evangelie" het 'n natuurteologiese basis en staan teenoor "die evangelie van die waarheid" (Gal 2:5; vgl Gal 2:14; 5:7) wat die "maatstaf" ("kanon") is vir wat voor God aanvaarbaar is. Hierdie "maatstaf" is die "evangelie van Christus/Jesus" (1 Tess 3:2; 1 Kor 9:12: 2 Kor 2:7; 9:13; 10:14; Gal 1:7; Fil 1:27; Rom 15:19) (kyk Dunn 1998:166; vgl Van Aarde 2002:516).

Die argument "look to the person rather than the act" is gevaarlike terrein. Dit verval in die dualisme wat die eenheid van liggaam, siel en gees ontken: "[T]he way we act with our bodies can't be separated from the rest of who we are, and in matters of sexuality it couldn't be closer" (Doe 2000:110). Doe vind dit ironies dat die kerk meer begaan is oor fisiese bevrediging as oor wat twee persone vir mekaar beteken. As terapeut wat ingestel is op die welsyn van mense, wil hy die klem eerder lê op vriendskap. Die gebrek aan ruimer verhoudingsmoontlikhede as net die seksuele dryf moontlik mense wat miskien 'n behoefte het aan 'n ander soort relasie tot die een of die ander: homoseksueel of heteroseksueel, want dit is al wat bestaan (Doe 2000:110). 
Eintlik behoort die kerk meer te fokus op verhoudings wat iets weerspieël van die liefde van Christus, as hoe dit fisies tot uitdrukking gebring word.

Die laaste woord oor hierdie onderwerp behoort sekerlik 'n pastorale een te wees. Oor ' $n$ benadering tot die pastorale versorging van homoseksuele mense stel Seitz (2000:181) dit soos volg: "One gets a sense that the proper pastoral stance is now one of lifting sexual taboos, raising cultural consciousness, encouraging 'outed' lifestyles ..." Alle pastorale werk word aangepak met hoop: die hoop dat mense in Christus verlos en heel sal kan lewe (Coleman 1980:282). Heelheid en verlossing is sinoniem in die Skrif (Wilkinson 1988). Vir die pastor, soos vir die kerk, is dit belangrik om altyd te onderskei tussen wat daartoe sal bydra en wat nie. Myns insiens sou die kerk van Jesus Christus aan die begin van die een-en-twintigste eeu die volgende getuienis kon lewer ten opsigte van homoseksualiteit:

- $\quad$ Die kerk weet dat die Bybel negatiewe kultuur-bepaalde uitsprake bevat oor wat vertaal word met "homoseksuele gedrag" Die kerk is die ruimte waarin die "geestelike liggaam" bestaan. Die bedoeling van die Heilige Skrif is nie om kulturele gewoontes as norme voor te hou nie, maar om God se versoening aan mense bekend te maak. Die kerk leef uit hierdie evangelieboodskap. Die versoening met God berus op geloof alléén. Niks van die menslike natuur kan hierdie versoening bewerkstellig nie. God se Gees maak dit vir mense moontlik om hulle hele lewe (ook die liggaam) in God se diens te stel.

- Die kerk weet dat daar mense is met 'n homoseksuele oriëntasie en dat van hulle lidmate is van die kerk, van hulle die kerk verlaat het en van hulle niks met die kerk te doen wil hê nie. Gelowige homoseksuele persone wat lidmate is, verlang van die kerk pastorale sorg en morele leiding vir hulle Gees-gevulde lewe in God se teenwoordigheid.

- $\quad$ Die kerk glo dat alle gedooptes, alle gelowiges ongeag hulle seksuele oriëntasie, lede van die liggaam van Christus is. Die handhawing van die eenheid van die kerk as liggaam van Christus is 'n evangeliese eis. Daarom is gays welkom in die geloofsgemeenskap.

- $\quad$ Die kerk onderneem om pastoraal te luister na die verhale van homoseksuele persone se ervaring en hulle te verseker van die liefde van God en van medegelowiges.

\section{Literatuurverwysings}

American Psychiatric Association 2000. Fact sheet of the American Psychiatric Association, revised May 2000.

Anthonissen, C \& Oberholzer, P 2001. Gelowig en gay? Riglyne vir 'n sinvolle dialoog met gay lidmate in die gemeente. Kaapstad: Lux Verbi. 
Balch, D L 2000. Concluding observations by the editor, in Balch, D L (ed), Homosexuality, science, and the "plain sense" of Scripture, 278-304. Grand Rapids, MI: Eerdmans.

Bellis, A O \& Ogden T L 2002. Science, Scripture and homosexuality. Cleveland, $\mathrm{OH}$ : The Pilgrim Press.

Berger, P L 1969. The sacred canopy: Elements of a sociological theory of religion. London: Faber and Faber.

Berger, P L 1973. The social reality of religion. Harmondsworth: Penguin Books.

Berger, P L 1992. A Far Glory: The quest for faith in an age of credulity. New York, NY: Free Press.

Beukes, S A 2003. Homoseksualiteit en die kerk. MDiv-skripsie, Universiteit van Pretoria.

Bird P A 2000. The Bible in Christian Ethical deliberations concerning homosexuality: Old Testament contributions, in Balch, D (ed), Homosexuality, science, and the "plain sense" of Scripture, 142-176. Grand Rapids, MI: Eerdmans.

Brawley, R L (ed), Biblical ethics \& homosexuality: Listening to Scripture, 69Louisville, KY: Westminster John Knox.

Brooten, B J 1996. Love between women: Early Christian responses to female homoeroticism. Chicago, IL: The University of Chicago Press.

Bultmann, R 1951. Theology of the New Testament, Vol 1. New York, NY: Charles Scribner's Sons.

Cameron-Ellis, J A 1999. Church and homosexuality: The relationship between individual religious beliefs, attitudes and the quality of contact. MA Thesis, University of Pretoria.

Coleman, P 1989. Gay Christians - a moral dilemma. London: Trinity Press International.

Conger, J J 1975. Proceedings of the American Psychological Association, Incorporated, for the year 1974: Minutes of the annual meeting of the Council of Representatives. American Psychologist 30, 620-651.

Countryman, L W [1988] 1989. Dirt, greed and sex: Sexual ethics in the New Testament and their implications for today. Second printing. Philadelphia, PA: Fortress.

De Gruchy, S 1997. Human being in Christ: Resources for an inclusive anthropology, in Germond, P \& De Gruchy, S (eds), Aliens in the household of God: Homosexuality and Christian faith in South Africa. Cape Town: David Philip Publisher.

Doe, M 2000. Seeking the truth in love: The church and homosexuality. London: Darton, Longman \& Todd.

Dollimore, J 1991. Sexual dissidence: Augustine to Wilde, Freud to Foucault. Oxford: Clarendon Press.

Dunn, J D G 1998. The theology of Paul the apostle. Grand Rapids, MI: Eerdmans.

Edwards, G R 1984. Gay/lesbian liberation: A biblical perspective. New York, NY: Pilgrim.

Edwards, E G 1996. Exploring the implications of Paul's use of sarx (flesh), in Brawley, R L (ed), Biblical ethics \& homosexuality: Listening to Scripture, 6986. Louisville, KY: Westminster John Knox. 
Ellison, M M 1993. Homosexuality and Protestantism, in Swidler, A (ed), Homosexuality and world religions, 149-179. Valley Forge, PA: Trinity Press International.

Erdokimov, P 1985. The sacrament of love: The nuptial mystery in the light of the Orthodox tradition, tr by A P Gythiel \& V Steadman. Crestwood, NY: St Vladimir's Seminary Press.

Furnish, V P 1979. The moral teaching of Paul: Texts and hermeneutics. Nashville, TN: Abingdon.

Gagnon, R A J 2001. The Bible and homosexual practice: Texts and hermeneutics. Nashville, TN: Abingdon.

Germond, P 1997. Heterosexism, homosexuality and the Bible, in Germond, P \& De Gruchy, S (eds), Aliens in the household of God: Homosexuality and Christian faith in South Africa, 188-232. Cape Town: David Philip.

Germond, P \& De Gruchy, S 1997. Aliens in the household of God: Homosexuality and Christian faith in South Africa. Cape Town: David Philip Publishers.

Geyser, P A 2002. Bybelse getuienis oor homosekualiteit - met ander oë gesien. HTS 58(4), 1655-1677.

Halperin, D M 1990. One hundred years of homosexuality and other essays on Greek love. New York, NY: Routledge.

Hanigan, J P 1988. Homosexuality: The test case for Christian sexual ethics. New York, NY: Paulist Press.

Hays, R B 1996. The moral vision of the New Testament: Community, cross, new creation: A contemporary introduction to New Testament ethics. San Francisco, CA: HarperSanFrancisco.

Hazel, D 2000. Witness: Gay and lesbian clergy report from the front. Louisville, KY: Westminster John Knox.

Hunter, D G 1992. Marriage in the Early Church, edited and translated by D G Hunter. Minneapolis, MN: Augsburg Fortress. (Sources of Early Christian Thought.)

Immink, F G 2003. In God geloven: Een praktisch-theologische reconstructie. Zoetermeer: Meinema.

Johansson, W 1990. s v Judeo-Christian tradition. The Encyclopedia of Homosexuality, Volume 1, 648-649, edited by W R Dynes. New York, NY: Garland Publishing.

Jones, S L \& Yarhouse, M A 2000a. Homosexuality: The use of scientific research in the church's moral debate. Downers Grove, IL: InterVarsity Press.

Jones, S L \& Yarhouse, M A 2000b. The use, misuse and abuse of science in the ecclesiastical homosexuality debates, in Balch, D (ed), Homosexuality, science, and the "plain sense" of Scripture, 73-120. Grand Rapids, MI: Eerdmans.

Jüngel, E 1962. Paulus und Jesus. Tübingen: J C B Mohr.

Kitzinger, C 1996. The psychologisation of lesbian relationships: The case against "Merger", in Mohin, L (ed), An intimacy of equals: Lesbian feminist ethics, 106-117. London: Onlywomen Press.

Laslett, P 1985. Societal development and aging, in Binstock, R H \& Shanas, E (eds), Handbook of aging and the social sciences. New York: Van Nostrand Reinhold. 
Malina, B J [1981] 1993. The New Testament world: Insights from cultural anthropology. Revised edition. Louisville, KY: Westminster.

Marder, J R 1989. Getting to know the Gay and Lesbian Shul: A rabbi moves from tolerance to acceptance, in Balka, C \& Rose, A (eds), Twiced blessed, 209217. Boston, MA: Beacon Press.

Martin, D B 1996. Arsenokoitês and malakos: Meanings and consequences, in Brawley, R L (ed), Biblical ethics \& homosexuality: Listening to Scripture, 117136. Louisville, KY: Westminster,

McNeill, J J 1988. Taking a chance on God: Liberating theology for gays, lesbians, and their lovers, families, and friends. Boston, MA: Beacon.

Melcher, S J 1996. The Holiness Code and human sexuality, in Brawley, R L (ed), Biblical ethics \& homosexuality: Listening to Scripture, 87-102. Louisville, KY: Westminster John Knox.

Neyrey, J H 1988a. A symbolic approach to Mark 7. Forum 4(3), 63-92.

Neyrey, J H 1988b. Unclean, common, polluted, and taboo. Forum (4), 72-8.

Neyrey, J H 1990. Paul, in other words: A cultural reading of his letters. Louisville, $\mathrm{KY}$ : Westminster.

Outka, G 1972. Agape: An ehtical analysis. New Haven, CT: Yale University Press.

Ricoeur, $\mathrm{P}$ [1986] 1991. From text to action: Essays in hermeneutics, II, tr by $\mathrm{K}$ Blamey \& J B Thompson. London: Athlone Press.

Scroggs, R 1983. The New Testament and homosexuality: Contextual background for contemporary debate. Philadelphia, PA: Fortress.

Seitz, C 2000. Sexuality and Scripture's plain sense: The Christian community and the law of God, in Balch, D L (ed), Homosexuality, science and the "plain sense" of Scripture, 177-196. Grand Rapids, MI: Eerdmans.

Seow, C-H 1996. Textual orientation, in Brawley, R L (ed), Biblical ethics \& homosexuality: Listening to Scriptures, 17-34. Louisville, KY: Westminster.

Simons, E L 1989. Human origins. Science 245, 1343-1350.

Smith, D W E 1993. Human longevity. Oxford: Oxford University Press.

Strommen, M P 2001. The church \& homosexuality: Searching for a middle ground. Minneapolis, MN: Kirk House Publisher.

Taylor, T 1996. The prehistory of sex. New York: Bantam Books.

Van Aarde, A G 1997-1998. Aanneming tot kind van God (hiuothesia) by Paulus in Romeine 8 teen die agtergrond van die Jerusalemse tempelkultus se huweliksmaatreëls. Skrif en Kerk 18(2), 345-355; 19(1), 96-114.

Van Aarde, A G 2000. Die relevansie van die historiese Jesus-ondersoek vir kerklike teologie. HTS 56(2\&3), 549-571.

Van Aarde, A G 2002. Die "evangelie" van Paulus. Verbum et Ecclesia 23(2), 516532.

Van den Aardweg, G 1985. On the origins and treatment of homosexuality. New York, NY: Praeger.

Van Zyl, H C 2002. Die Nuwe Testament en seksualiteit. Acta Theologica 22(2), 234261.

Via, D O 2003. The Bible, the church and homosexuality, in Via, D O \& Gagnon, R A $\mathrm{J}$ (eds), Homosexuality and the Bible, 1-39. Minneapolis, MN: Fortress.

Vinovskis, M A 1971. The 1789 Life Table of Edward Wigglesworth. Journal of Economic History 31, 579-590. 
Waetjen, H C 1996. Same-sex relations in antiquity, in Brawley, L B (ed), Biblical ethics \& homosexuality, 103-116. Louisville, KY: Westminister.

Wilkinson, J 1988. The Bible and healing: A medical and theological commentary. Edinburgh: Handsel Press. 